\title{
Desvelando as Malhas \\ da Escrita: Entre o Mito \\ e a Realidade
}

Maria Heloísa Martins Dias* 
Ascêncio de Freitas, escritor português que viveu em Moçambique, acaba de receber o Prêmio Pen Club por seu romance O canto da Sangardata (2000). Autor de diversas obras como Ontem era madrugada, À boca do passado, Na outra margem da guerra, A reconquista de Olivença, que lhe valeu o Prêmio Literário Vergílio Ferreira -1999. Está mais do que na hora, parece-me, de reconhecer a qualidade de sua escrita ficcional, radicada numa intensa consciência das tensões entre palavra e realidade, aquela despontando como signo dotado de potencialidades agenciadoras de transformação. É o que vamos descobrindo ao percorrer sua obra.

Leio o título de seu conto "Amanhece, manhã, amanhecendo", extraído de Ontem era madrugada (1978), e ele me impulsiona, de imediato, a uma percepção múltipla de seus efeitos. Digamos que ele faz acordar relações inusitadas entre som e sentido. $\mathrm{O}$ amanhecer, assim anunciado (e enunciado), destaca-se como realidade dinâmica cujos movimentos e formas se presentificam: a recorrência dos sons criada entre os três termos alerta para um procedimento que será retomado ao longo do conto. Trata-se da interpenetração do espaço natural à linguagem, realidades que passam a existir em conaturalidade; assim, falar do mundo é corporificá-lo pela linguagem, isto é, a transparência da natureza é também uma transparência da linguagem que a recupera.

À medida que vamos percorrendo essa narrativa, essa espécie de acordo entre natureza e palavra, ou essa curiosa "sintaxe" tecida entre elas, torna-se cada vez mais intensa, graças ao destaque de uma sonoridade que 
vem das coisas. Há um deixar o mundo dizer suas formas e funções mágicas, em que animais e fenômenos naturais vão despertando como se animados por uma força, que já não é apenas deles mesmos, mas da linguagem que os faz surgir:

"As friagens no desamparo cru do vento e os grilos nos últimos cantos, mil, mil, teimados em não dormir, ainda o em-cheio grosso dos sapos, no rio."

Encantamento mítico, fala poética em sua função mais próxima do mundo primitivo e original. A originalidade, aqui, está nesse dar voz às coisas e acolhê-las em seu ser imediato, fenomênico. E o resultado só poderiam ser construções inusitadas, dotadas de uma lógica própria ou uma pré-lógica instaurada por esse dizer autêntico:

"E o sobre de tudo o mor rumor, o ronco do rio, continuado, nas miúdas cataratas. Da outra margem, tutuando, o serenoso assobio da garça-torda, tutu-huá, tutu-huá, dona da sua voz." Como se vê, poesia e mito se encontram nesse rito criado pelo ato de contar. Entretanto, essa "fala mitopoética", expressão de Alfredo Bosi (1977), não busca reviver, de maneira inocente, a sacralidade e heroísmo de tempos originários, porque o mundo natural que aqui desponta sobrevive em meio a outros tempos, bem mais sombrios e cruéis. É o que o conto irá mostrar em seu desenvolvimento.

Em outro momento (1995), já comentei sobre esse caráter mitopoético da narrativa, ao comparar contos de Guimarães Rosa e Luandino Vieira. Vejo, agora, que a escrita ficcional de Ascêncio de Freitas também se alimenta desse modo tão peculiar de construir as relações entre linguagem e mundo, ambos "encantados" (no dizer de Guimarães Rosa) por suas virtualidades mágicas. Mas é preciso que se entenda esse mágico em seu real significado. Não se trata, apenas, de uma postura inocente, virginal, diante do mundo para descobri-lo e depois representá-lo; trata-se, antes, de um deslumbramento (Manuel Bandeira diria “alumbramento") armado também de consciência em relação ao fazer poético, que se tece, principalmente, de discrepâncias. Trata-se, afinal, de um estar atento às configurações armadas pela realidade e recriadas pelos sobressaltos da linguagem. Ou, para dizer com Guimarães Rosa, "o mundo é todo encantado. Instante esti- 
ve lá, por um evo, atento apenas ao auspício.” (1985). Aproveitando a metáfora que figura no conto de Ascêncio de Freitas, trata-se de um "acordar olho ante olho", belíssima expressão para caracterizar esse olhar lento mas profundo e sensível, "atento ao auspício", que vai acordando junto com as coisas e investindo nas potencialidades de sua percepção:

"O mundo falando claro e por inteiro as muitas vozes da madrugada, madrugar, o cloquear das galinhas, o coinco vago e rouco dos porcos, fixas as vozes, muitas, dos passarinhos arredores acordando, e os croticos das aves do rio. Rumores que o vento traz e o vento, ainda, chocalhando as folhas. Farfalhame. Cheiros de húmus, cheiro de águas, diversas."

Mas, se o início do conto demora-se em singularizar o cenário natural, em que linguagem e espaço aparecem fundidos, por que essa insistência? É que o minucioso e vagaroso acordar da manhã, captado pelo "olho ante olho" do narrador (e não apenas do personagem por ele focalizado), serve como contraste com outro universo que irá despontar mais adiante: o da aspereza e crueldade do ser humano investido de poder. Se a garça-torda é dona de sua voz, esse poder em nada se parece com outro, que irá chocar o leitor pela violência com que se impõe. Desse modo, ao poder ancestral do mundo, em que rio, árvores, nuvens, manhã, céu, sol e aves trabalham suas metamorfoses ou ritos naturais, contrapõe-se um outro poder, também de secular duração - o do homem que se sente dono do mundo e de outros homens a ponto de subjugá-los, espezinhando-os. Então, a voz que passa a soar não mais acolhe, ao contrário, espanta e destrata: "-Cão-cachorro.” ; - Esse mata-bicho!..."

Mas vamos aos fatos.

No primeiro momento do conto o que surge diante do leitor, além da focalização do amanhecer, é o homem, personagem não nomeado e que mais adiante sabemos tratar-se de um patrão de trabalhadores na cacimba. Não é por acaso, portanto, que sua presença se destaque logo no início da narra- 
tiva; estratégia hábil, talvez, de mostrá-lo como eixo condutor ou cabeça de um círculo que só existe por força de sua presença. E mais: o preciosismo com que seus gestos vão sendo caracterizados, até mesmo os mais banais e rasteiros (lavar a cara, coçar a barba, mijar), acaba por compor uma figura que vai sendo violada na sua intimidade. Assim, o que poderia inspirar autoridade ou respeito ("Disposto, valor e ânimo.") acaba se desmascarando porque visto com olhos realistas.

Investindo na técnica do contraponto, o olhar crítico do narrador focaliza outras personagens - o grupo de trabalhadores - cujas características os distanciam totalmente do patrão. "O andar duro-hirto" por causa do frio e "o sopro tremido das muitas vozes que mal se ouvem" criam a imagem do ser coletivo, opondo-se à individuação do senhor. Vozes que, apesar de unidas, são tremidas e pouco nítidas, são vozes que não têm a força suficiente para atingir o outro ou encontrarem ressonância que reforce uma luta comum. A mensagem indiciada por tal caracterização começa a despontar: não é apenas o frio que os atemoriza, mas um poder que os enrijece mais que o próprio tempo.

Os contrastes, aliás, constituem o recurso composicional mais significativo dessa narrativa. As tensões dialéticas que emergem do jogo entre as cenas, os diálogos e os motivos ao longo do conto apontam, no fundo, para o seu tema maior: o conflito entre opressor e oprimido.

Destaco, por exemplo, o diálogo travado inicialmente entre o patrão e o capataz. Se este, ao se comunicar, é movido por exclamações, um ritmo intenso e uma vibração espontânea, "falando, no ponto justo as humildades", como reconhece o narrador, aquele (patrão) expõe lacônica e secamente suas ordens, com “a voz torrada de patrão e senhor”, cortando qualquer possibilidade de um envolvimento maior:

“- Bom dia, patrão!

- Bom dia.

- Continua o serviço de ontem?

- Continua.

- Bem, patrão.

- Diz ao tratorista que venha cá.” 
Na verdade, o diálogo prossegue, retardando a entrada em cena desse outro personagem anunciado, o tratorista. $\mathrm{O}$ tema da conversa afigura-se, aparentemente, sem propósito, o que gera indignação no patrão e acionando ainda mais sua (in)diferença em relação ao empregado. O motivo é a venda de um barco oferecido ao homem, proposta recusada por este. Mas tal recusa, que implica o abandono desse episódio e sua retirada de cena pelo narrador, permanecerá reticente e latente no conto para retornar, como antítese e imprevisível, no final da história. Eis aí mais uma curiosa oposição tramada por essa ficção. A passagem de um viajante que se aproxima do local para pedir auxílio por causa do carro é manipulada com engenhosidade na montagem da narrativa, justamente por propiciar o jogo de contrastes que move a cruel lógica do sitiante em suas atitudes. Se a princípio, ele não vê utilidade nenhuma na compra de um barco ("- Mas pra que diabo quero eu um barco?'), diante do estranho visitante a inutilidade se transforma em instrumento de ostentação de poder, e o despropósito de antes agora é um firme propósito de assegurar status. Numa interessante inversão de papéis, o absurdo anteriormente questionado pelo patrão agora está na boca do visitante: "-Mas para que raio precisa o senhor aqui de um barco?”. Ora, como a única lógica que move o proprietário é a dos interesses imediatos e não a da coerência ou verossimilhança, a conversa entre ele e o estranho acaba esvaziando-se e se sustentando apenas pelo frágil fio das repetições ocas. A função fática denuncia a sem-razão dos fatos:

“- Bem... Faz sempre falta. Não acha que um barco faz sempre falta?

— Não há dúvida. Um barco por vezes faz falta.

- Pois faz."

O cruel, nesse caso, ou noutros termos, a ironia que se articula na linguagem está precisamente em remeter o leitor para o contraste das situações: antes, a negação da idéia tida como absurda, agora, a apropriação da idéia como necessidade legítima. Que distância entre esta maldosa engrenagem do sistema econômico-social e a "engrenagem" mitopoética do espaço natural que emoldura a narrativa! É como se duas realidades se intercalassem no conto de Ascêncio de Freitas, fazendo despontar suas di- 
ferenças: o mundo das relações autênticas e naturais em sua esfera primitiva, autóctone, e o mundo das relações conflitivas e desumanas do círculo opressor. $\mathrm{O}$ choque entre amenidade e violência permeia a narrativa, o que se reflete, por exemplo, no jogo entre o trato com a paisagem e o trato com o elemento humano. Enquanto para a primeira há uma plena abertura ao acolhimento das potencialidades poéticas, numa espécie de cumplicidade com o mundo natural, para focalizar as relações humanas (patrão x empregado) não há suavidade alguma, pois marcadas pela traição.

Assim, descortina-se uma luminosidade - "e o sol vesperando, seu anunciado de muita luz a esprair, o céu no remudamento das cores, influindo júbilos do dia a nascer" - que conflita com a densidade sombria que cerca os contatos humanos: "C' rrá, c' rrá, c'rrá. Nada. O rabo do olho do homem, desconfiado, em cima do tratorista. Nenhum falou." O som da chave tentando fazer o motor pegar, reproduzido pela onomatopéia e coexistindo com o silêncio, atua no lugar da pessoa como se anulando-a, como se mais importante fossem as coisas e não os seres humanos. De resto, somente o nada e a desconfiança. $\mathrm{O}$ episódio exibe com violência o pleno exercício da tirania do sitiante em confronto com o tratorista. Ostentando seus poderes sobre o mais fraco, o patrão ainda o obriga a reforçar traços depreciativos de si mesmo, numa perversa antiterapia:

“- Negro é malandro, não é?

(...)

- Fala rapaz. É ou não é?

- Nosso não viu. Pensava...

- Fala direito, rapaz. É ou não é malandro?

- É, sim, patrão.

- Negro é bandido. É ou não é?

- É, sim, patrão.

- Negro é filho da mãe. É ou não é?

- É, sim, patrão.

- Negro pra trabalhar direito precisa apanhar porrada. Precisa ou não precisa?

— Nosso não viu, patrão... Faz favor...” 
O diálogo concretiza e, mais do que isso, dramatiza, os efeitos reais da opressão sobre o indivíduo, na medida em que este é forçado a uma absurda aprendizagem: incorporar e aceitar valores desumanos, preconceituosos e distorcidos. Ser negro é malandragem e banditismo, falar à sua maneira é ser burro, o trabalho vale como exploração, apanhar é necessário. Enfim, diante dessa "lógica" em que impera a insensibilidade do autoritarismo, não há o que dizer, muito menos o claudicante pedido de favor do tratorista para a não violência. Ela acaba acontecendo, como é previsível (mas jamais aceitável) no contexto desse sistema que envolve opressor e oprimido. A simples falta de combustível no trator se preenche com a mais grotesca imagem da violência: "o homem atirou-se para a frente, num pontapé a meio da barriga, fazendo-o cair, prancheado, estatelado contra o tronco grosso da muonha."

Embora não estejamos diante de um romance marcado, segundo a conceituação de Lukács, pela presença de um "herói problemático", esse caráter "demoníaco", termo também lukacsiano, assinala a degradação dos valores autênticos própria do sistema econômico-social em que está instalado o protagonista do conto. Não é demais vermos na construção narrativa do conto de Ascêncio de Freitas procedimentos composicionais que figurativizam relações de contraste, oposição e conflito, características da realidade social, o que corresponderia à "homologia estrutural" de que nos fala Lucien Goldmann ao analisar a forma romanesca (1967). No entanto, aplicar a "sociologia do romance" à investigação do texto narrativo não é meu intuito nesta leitura.

Totalmente alheio à crueldade que praticara, como se nada tivesse acontecido, o personagem retorna a seu cotidiano, recolhendo-se à casa, como o conto nos mostra na cena seguinte. Assim como o ritual diário do amanhecer, ao cumprir seu ciclo de normalidade, o gesto violento do homem parece ter se cumprido como uma necessidade normal, como mais uma ação na sua prática diária de má consciência social: "Tudo virado normal, desimaginado mas amadrugando (...)” Não fosse o imprevisível criado na linguagem, onde o imaginar e o "desimaginar" operam ricas trocas para seu funcionamento poético, tudo seria muito árido e desagradável para o nosso olhar. Até mesmo o intratável protagonista desse conto acaba sendo envolvido, em alguns poucos momentos, por um halo de poeticidade, como 
se o olhar do narrador desejasse limpá-lo da sujeira de seu caráter: "O homem, na varanda, esperando, manhã maior, já, nos ares limpos, o sol ganhando o céu (...)”. Acontece que essa limpeza não é possível em quem já está corrompido por vícios como o mando, a ameaça, a tirania. Não há linguagem poética capaz de restituir-lhe a menor pureza.

Novamente recorro à cena final do conto, onde mais um contraste acaba por acentuar a impureza ético-social do sitiante. Ao perceber que há um problema com o carro do estranho - rompimento do tubo de gasolina -, o homem não hesita em ajudá-lo, solícito e hospitaleiro. A hospitalidade não deixa de soar grotesca, na medida em que não passa de mais um hábil artifício do narrador para que seja desmascarada. Ela só existe como aparência, facilmente desmentida pela cena anterior com o tratorista, que fora espancado exatamente por causa da falta de gasolina no trator. Como se vê, um mesmo peso, duas medidas.

Desse modo, não é difícil ver na figura do tirano a ambigüidade que o cerca. A ousadia que lhe assegura o poder é a face visível de uma contraface, a da incoerência e fragilidade que o movem intimamente. Como diria Octavio Ianni, esse senhor "aparece traiçoeiro e feroz, ao mesmo tempo que equívoco e simulacro". Cabe ao artista denunciar essa ficção, mostrá-lo como "uma invenção de si mesmo". (1983).

Quero terminar este rápido percurso de leitura do conto de Ascêncio de Freitas, remetendo os dados analisados a uma visão mais ampla.

Se o tema da opressão está presente nessa escrita ficcional, reflexo esta de um espaço que já conquistou sua liberdade - o território africano -, é porque esse contexto ainda está atuando, de modo não mais explícito nem real, nas consciências. Se "ontem era madrugada", como propõe o título da obra, hoje o amanhecer pode ainda não ter dissipado as sombras dessa noite...

A libertação de regimes opressores ou de dependência política, por meio da descolonização, por exemplo, não significa que a sensação de aprisionamento não exista em outros níveis. Deslocado para a arte, e, portanto, ganhando uma resolução estética, o aprisionamento se transforma em dinâmicas formas de realização e de superação de seus conflitos, graças ao poder engendrado pela ficção.

É essa práxis instaurada pela linguagem na ficção de Ascêncio de Freitas que vale a pena desvelar com o exercício crítico. 


\section{REFERÊNCIAS BIBLIOGRÁFICAS:}

BOSI, Alfredo. O ser e o tempo da poesia. São Paulo: Cultrix/Edusp, 1977.

DIAS, Maria Heloísa Martins. "Narratividade mitopoética: Guimarães Rosa e Luandino

Vieira”. In: Jornal de Letras, Lisboa, 1995, p.42-43.

FREITAS, Ascêncio de. Ontem era madrugada. Lisboa: Bertrand, 1978.

GOLDMANN, Lucien. Sociologia do romance. Rio de Janeiro: Paz e Terra, 1967.

IANNI, Octavio. Revolução e cultura. Rio de Janeiro: Civilização Brasileira, 1983, p. 104.

ROSA, Guimarães. Ave, palavra. 3 ed., Rio de Janeiro: Nova Fronteira, 1985, p. 54. 